\title{
WINE, WOMEN, AND THE POLIS: GENDER AND THE FORMATION OF THE CITY-STATE IN ARCHAIC ROME
}

\author{
By BRIGETTE FORD RUSSELL
}

When my husband and I have dinner in a restaurant, if I order a steak and he orders a salad, the waiter almost invariably returns and puts the steak in front of him and the salad in front of me. Or in a bar, if I order Scotch and my husband orders Diet Coke, it is fairly certain that the waitress will come back and give him the whiskey and me the diet soda. Food and drink act in our society, as they acted in Roman society, as social signifiers. What a person eats and drinks conveys information about gender, class, and status. When a construction worker goes to a blue collar bar after work, the bartender fills his order of a beer without a second thought, but would probably stop and look twice at the man if he ordered a Campari and soda or a white wine spritzer. Popular culture, and film in particular, provides endless examples of this. We expect Audrey Hepburn as Holly Golightly to sip champagne cocktails, and Clint Eastwood as the high plains drifter to throw back a whiskey, neat. A drink can be such a meaningful signifier that every person who reads this will know immediately who is meant when a certain cinematic character is identified only by what he drinks: vodka martini, shaken, not stirred.

As Oswyn Murray writes in a study of the Greek symposion, or drinking party, 'just as society 'inhibits' or 'problematizes' sexual relations in order to control and use them, so it 'problematizes' another of man's most basic pleasures, that of eating and drinking, in order to create and support its socio-cultural structures. ${ }^{11}$ In this paper, I will examine how the Romans 'problematized' the consumption of wine by forbidding it to women. I will first examine some of the literary evidence for the Roman prohibition, and then review the archaeological testimony which partially refutes it. Next, I will discuss the social - and even the political - significance of wine in archaic Rome, setting this into comparative context with Greek and Celtic society, and also, more broadly, within the context of anthropological theory and ethnographic

\footnotetext{
${ }^{1}$ Oswyn Murray, 'Sympotic History', in O. Murray (ed.), Sympotica: A Symposium on the Symposion (Oxford, 1990), 5.
} 
studies of non-western cultures. Finally, I will address the connection between the prohibition on Roman women's consumption of wine and the rise of the Roman state.

According to Aulus Gellius, who wrote during the second century AD,

Qui de victu atque cultu populi Roman scripserunt mulieres Romae atque in Latio 'aetatem abstemias egisse,' hoc est vino semper, quod 'temetum' prisca lingua appellabatur, abstinuisse dicunt, institutumque ut cognatis osculum ferrent deprehendendi causa, ut odor indicium faceret, si bibissent.

Those who have written about the life and culture of the Roman people say that women in Rome and in Latium 'lived abstemious lives,' that is, they always abstained from wine, which was called 'temetum' in the ancient language, and that it was established practice that they would give their kinsmen a kiss for the purpose of discovering if they had been drinking, as the odour would be an indication. (Noctes Atticae 10.23.1) ${ }^{2}$

One of Gellius' sources for this ancient prohibition was the secondcentury BC moralist Cato the Elder. According to Gellius,

Marcus Cato non solum existimatas, set et multatas quoque a iudice mulieres refert, non minus si vinum in se, quam si probrum et adulterium admisissent.

Marcus Cato reports that women were not only judged but also punished by a judge no less severely if they had been guilty of drinking wine than if they had been guilty of unchastity and adultery. (NA 10.23.3)

Moreover, the punishment for a wife caught in adultery was, according to Cato, death:

in adulterio uxores deprehensas ius fuisse maritis necare

[It was written by Cato] that there was a legal right for husbands to kill wives caught in adultery. (NA 10.23.4)

The implication then is that a Roman husband was within his legal rights if he chose to kill his wife for drinking wine.

The powerful taboo surrounding female consumption of alcohol is also apparent in the ritual of the Bona Dea, the Good Goddess. ${ }^{3}$ The cult was celebrated by women only, and it was sacrilege for a man to be present. ${ }^{4}$ The ceremony involved an offer of wine to the goddess and presumably its consumption by the women celebrating the ritual. ${ }^{5}$

\footnotetext{
2 Translations are from the Loeb Classical Library unless otherwise indicated.

3 See H. H. Scullard, Festivals and Ceremonies of the Roman Republic (Ithaca, 1981), 199-201.

${ }^{4}$ One reason we know so much about this particular ritual, ironically, is that in $63 \mathrm{BC}$ a man did attend, profaning the rites by disguising himself as a woman and sneaking into the house for an illicit rendez-vous with one of the female participants.

${ }^{5}$ Scullard (n. 3), 220.
} 
But the forbidden wine was referred to as 'milk' (lac) and the jar containing it as a 'honey-pot' (mellarium):

vinum in templum eius non suo nomine soleat inferre, sed vas in quo vinum inditum est mellarium nominetur et vinum lac nuncupetur.

It was customary to bring wine into her temple not under its own name, but the vessel in which the wine had been put was called a honeypot and the wine was called milk. (Macrobius, Saturnalia 1.12.25)

The mythology of the goddess herself was also bound up with the taboo. According to Plutarch, the Bona Dea was the wife of the god Faunus, who caught her drinking wine and beat her to death for her transgression. ${ }^{6}$ Of significance also is the instrument of the intemperate woman's punishment: a branch of myrtle, the tree sacred to Venus, thus suggesting, as $\mathrm{M}$. Bettini points out, ${ }^{7}$ a connection between the woman's drinking and sexual impropriety. The relationship between chastity and sobriety need hardly be belaboured: the Romans knew as well as we do that inebriation leads to a relaxation of inhibitions.

The Romans disapproved of drunkenness in men as well as in women, as Cicero's invectives against the intemperate Marc Antony in the Philippics well demonstrate. Still, they were content to let men use their own judgment to moderate their consumption of wine, but considered it a matter of public morality to regulate that of women. This may be because of a general perception which emerges in the works of both Greek and Roman writers that women were less able to control their own unruly desires than were men. Or it may stem from what Sandra Joshel ${ }^{8}$ characterizes as a more deep-seated fear on the part of Roman men. In her view, Livy's narratives of Lucretia, who killed herself to cleanse the stigma of her rape, and of Verginia, whose own father killed her to prevent her violation, revolve literally around the preservation of female chastity and metaphorically around the preservation of patriarchal society. In both legends, Joshel maintains, the rape threatens not only the body of the female victim, but also the body politic. If she is right, then the prohibition of wine to women is more than just a petty attempt at social control of women by men, and becomes instead a safeguard to the purity of the Roman state itself.

${ }^{6}$ Quaestiones Romanae 268.

7 Maurizio Bettini, 'In vino stuprum', in O. Murray and M. Tecusan (eds.), In Vino Veritas (London, 1995), 229.

${ }^{8}$ Sandra Joshel, 'The Body Female and the Body Politic: Livy's Lucretia and Verginia', in A. Richlin (ed.), Pornography and Representation in Greece and Rome (Oxford, 1992), 112-30. 
The Romans of the late Republic and early Empire believed that the prohibition on women's consumption of wine was part of the mos maiorum, the ancient code of morality handed down by their venerable ancestors through the mists of antiquity. Yet this was not in fact the case. The archaeological record of the preceding archaic period indicates that women in Rome and other Latin towns did in fact take part in the aristocratic culture of feasting and wine-drinking.

Excavations conducted in Latium during the past several decades have uncovered a number of cemeteries containing burials from the eighth, seventh, and sixth centuries. ${ }^{9}$ Elite male burials of the eighth century are distinguished by arms and armour which testify to aristocratic warrior status. In the seventh century, arms give way to articles of convivial display. ${ }^{10}$ Significantly, female burials also contain the paraphernalia of feasting and drinking: mixing bowls on folding bronze stands, and Punic amphorae containing imported Sardinian wine. ${ }^{11}$ Thus the Latin matron of the seventh century emerges as a hostess who presides over the mixing and serving of wine at the banquets which were such an integral part of aristocratic culture in Central Italy during the seventh century.

It was during this time, known as the Orientalizing period, that Greek colonists were settling in Southern Italy and Sicily, and Phoenician traders were establishing themselves in Sardinia and Sicily. In the wake of this foreign penetration, Italian villages began to take shape as real cities. Both Latins and Etruscans adopted the Greek hoplite panoply of weapons, and began to bury their dead with luxury goods either imported from Greece or fashioned by immigrant Greek craftsmen in Italy. Especially significant among these eastern imports were vessels for the storing, mixing, serving, and drinking of wine.

In her study of the aristocratic banquet in Central Italy, Annette Rathje argues that the Homeric banquet was the most important element in the Hellenic cultural practices transmitted to the élites of Latium and Etruria. R. Ross Holloway, however, cautions against attributing the social ritual of the banquet exclusively to Hellenizing influence. He points to a Bronze Age Sicilian table service as evidence of a native culture of conviviality. ${ }^{12}$ Although similar evidence has not been

\footnotetext{
9 R. Ross Holloway, Archaeology of Early Rome and Latium (London, 1994), Chapter 9.

${ }^{10}$ Holloway (n. 9), 117.

11 Annette Rathje, 'The Adoption of the Homeric Banquet in Central Italy in the Orientalizing Period', in O. Murray (ed.), Sympotica (n. 1), 282-3.

12 Holloway (n. 9), note 3 on pp. 191-2.
} 
found on the Italian mainland, Holloway argues that there is no reason to believe that these social traditions did not arise indigenously, and only acquire 'foreign trappings' later. ${ }^{13}$

A study of the theoretical literature of comparative anthropology suggests that Holloway is right. Enthographic studies of pre-state societies in many different parts of the world illustrate the importance of convivial display in the politics of prestige. In a study of social and political organization in Melanesia and Polynesia, Marshall D. Sahlins discusses a level of political organization below that of the chiefdom, a world of personal politics dominated by what he calls the big-man. As he describes them,

Big-men do not come to office; they do not succeed to, nor are they installed in, existing positions of leadership over political groups. The attainment of big-man status is rather the outcome of a series of acts which elevate a person above the common herd and attract about him a coterie of loyal, lesser men. ${ }^{14}$

The anthropological construct of the big-man has been applied with very stimulating results to the Greek Dark Age by Walter Donlan ${ }^{15}$ and by Bjørn Qviller, ${ }^{16}$ and can also be applied to early Roman society. In this view, the aristocrats of archaic Latium and Etruria, like Homer's basileis and Sahlins' Melanesian headmen, competed with one another for prestige and power by ostentatious displays of martial valour, gift giving, and feasting. Anthropologist Morton H. Fried calls big-men 'the private redistributors whose power is as fragile as their last successful party'. ${ }^{17}$

Feasting and wine-drinking were likewise an important social ritual in the Late Hallstat phase of Celtic society in Western Europe (ca. 600-400 BC). Bettina Arnold discusses how 'rank and status differences are represented in the burial record by drinking and feasting paraphernalia as well as by personal ornament. ${ }^{18}$ The subsequent period, Early La Tène, saw the development of what archaeologists

13 Holloway (n. 9), 192.

14 Marshall D. Sahlins, 'Poor Man, Rich Man, Big-Man, Chief: Political Types in Melanesia and Polynesia', Comparative Studies in Society and History 5 (1963), 285-303, at 289.

15 Walter Donlan, 'The Pre-State Community in Greece', Symbolae Osloenses 64 (1989), 5-29; 'The Social Groups of Dark Age Greece', Classical Philology 80 (1985), 293-308; 'The Politics of Generosity in Homer', Helios 9 (1982), 1-15.

16 Bjørn Qviller, 'The Dynamics of Homeric Society', Symbolae Osloenses 56 (1981), 109-55.

17 Morton Fried, The Evolution of Political Society (New York, 1967), 232.

18 Arnold, Bettina, 'The material culture of social structure: rank and status in early Iron Age Europe', in Bettina Arnold and D. Blair Gibson (eds.), Celtic Chiefdom, Celtic State (Cambridge, 1995), 43-52, at 44. See also Michael Dietler, 'Early "Celtic" socio-political relations: ideological representation and social competition in dynamic comparative perspective', in Arnold and Gibson, 64-71, at 65-66. 
refer to as Fürstengräber, or 'princely tombs' which can be compared to the lavish Etruscan and Latin burials of the Orientalizing period, such as the famous Praeneste tombs. ${ }^{19}$ The La Tène burial record, like the Latin, testifies to women's participation in the important social rituals of feasting and wine-drinking.

In Celtic Europe, as in Latium, we have only the burial record to testify to female participation in aristocratic social rituals, but in Etruria we have pictures which are worth a thousand amphorae. The tomb paintings of Etruscan aristocrats depict scenes in which men and women recline side by side on dining couches, sharing as apparent equals in the food and wine of the banquet. The contrast could not be sharper between the archaic Etruscan banquet and the Greek symposion of the classical period. The Greek symposion was an essentially all-male affair, where the only women present, if any, were slaves and prostitutes. ${ }^{20}$

The social status of aristocratic Roman women during the seventh century thus bears more resemblance to that of archaic Etruscan and La Tène Celtic women than it does to that of Greek women in the classical period, or even to that of Roman women in the later Republican period. A connection would seem to exist between political forms and the structure of gender relations. Greek women of the Dark Age, as reflected in the epics of Homer, seem to have enjoyed a higher social status than their great-granddaughters of the classical period, when the organized polis had supplanted the footloose world of big-men jockeying for status and power through displays of bravery, generosity, and conviviality. In the classical polis, service in the hoplite army and in the assembly of armed men constituted the primary axis of identification, and those whom nature created to bear children rather than arms were excluded from the formal practice of politics. And since social relations in the polis were almost indistinguishable from political relations, women tended to be marginalized socially as well. It is in the context of such a society that we must understand the outrage expressed by the fourth-century BC Greek historian Theopompus at the Etruscans, because these people were so utterly lacking in decency that they let their women recline with them at banquets. Greek disapproval of Etruscan women indicates that the conduct of the women of archaic central Italy did not conform to the standards of female behaviour in settled polis conditions.

19 See Dietler (n. 18) on the comparison.

20 Murray (n. 1), 6. 
Once the Romans had completed the transition from aristocratic bigman society to Republican polis, they too began trying to shape their women into chaste and obedient wives and daughters. It would not be surprising if Greek influence had some hand in this process, though this is not reflected anywhere in the sources. On the contrary, one can imagine the outrage of Cato the Elder at the very idea.

Echoes of a bygone age of feminine social and political prominence survive in the Republican invectives against the unruly women of the regal period. Tanaquil ${ }^{21}$ and Tullia, ${ }^{22}$ the wives of the two Tarquin kings, play roles in the Roman historical tradition which contrast sharply with the passive functions accorded to Republican heroines like Lucretia and Verginia.

The formalization of state structures never really put an end to family politics in Rome, as becomes apparent by even a cursory glance at the stemmata of aristocratic families of the middle and late Republic. The prominence of Roman matriarchs like Cornelia, mother of the Gracchi, provides further testimony to the social prominence of aristocratic Roman women vis à vis their Greek counterparts. In general, however, it was the tie of citizenship rather than kin that bound Romans one to another, as is illustrated by the multitude of stories in which Romans put country over family, for example: Veturia and her son Coriolanus, ${ }^{23}$ Brutus and his sons, ${ }^{24}$ Torquatus and his son, ${ }^{25}$ and so forth.

A well-known episode from Livy illustrates well the transition from old to new values. The sons and nephews of Tarquinius Superbus were sitting around the army camp one night, drinking and arguing over who among them has the most virtuous wife. Tarquinius Collatinus, insisted that his wife Lucretia would win the contest hands down. The princes 'had grown heated with wine' (incaluerant vino, 1.57.8), and Collatinus offered to put his money where his mouth was. So they got on their horses and rode off to check on their wives, coming at last to the house of Collatinus,

ubi Lucretiam haudquaquam ut regias nurus, quas in convivio luxuque cum aequalibus viderant tempus terentes, sed nocte sera deditam lanae inter lucubrantes ancillas in medio aedium sedentem inveniunt.

where they saw Lucretia not at all as they had seen the royal daughters-in-law, whom they had seen wasting time in conviviality and luxury with their peers, but late at night

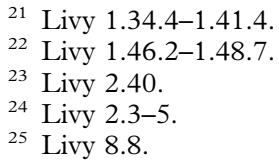


they found her sitting by lamplight in the centre of the house among her slave women, dedicated to her wool. (1.57.9)

Here in the persons of the princesses we see the Roman women of the archaic period, socializing at a sumptuous banquet with their friends (in convivio luxuque cum aequalibus). As their husbands sat around the army camp drinking wine and boasting about their wives, so too did the women sit together in one of their homes sharing food, wine, and conversation. This Livy condemns as 'wasting time' (tempus terentes), although he makes no comment regarding the productivity of the princes' time, spent 'growing heated with wine' (incaluerant vino) and making bets on whose wife was better than whose. The winner, of course, was the husband of Lucretia, the prototype of the new woman of the Republican polis, who, while her husband drank wine with his friends, sat soberly among her slave women, 'dedicated to her wool' (deditam lanae).

\section{NOTES ON CONTRIBUTORS}

L. P. E. PARKER: Emeritus Fellow in Classical Languages and Literature at St. Hugh's College, Oxford.

PAUL CHRISTESEN: Assistant Professor of Ancient Greek History at Dartmouth College, Hanover, New Hampshire.

GABRIEL DANZIG: Lecturer, Department of Classical Studies at Bar Ilan University, Israel.

BRIGETTE FORD RUSSELL: Lecturer in History at Loyola Marymount University, Los Angeles.

FRANCES TITCHENER: Professor of History and Classics at Utah State University. 